\title{
Alkali activation-granulation of hazardous fluidized bed combustion fly ashes
}

Juho Yliniemi ${ }^{\text {a }}$, Janne Pesonen ${ }^{\text {b }}$, Pekka Tanskanen ${ }^{\mathrm{c}}$, Olli Peltosaari ${ }^{\mathrm{c}}$, Minna Tiainen ${ }^{\mathrm{d}}$, Henk Nugteren ${ }^{\mathrm{e}}$, Mirja Illikainen ${ }^{\mathrm{a}, *}$

${ }^{a}$ Fibre and Particle Engineering, P.O. Box 4300, University of Oulu, 90014 Oulu, Finland

${ }^{b}$ Sustainable Chemistry, P.O. Box 3000, University of Oulu, 90014 Oulu, Finland

${ }^{c}$ Process metallurgy, Faculty of Technology, P.O. Box 4300, University of Oulu, Oulu 90014

Finland

${ }^{d}$ Inorganic Chemistry, Center for Molecular Materials, P.O. Box 3000, 90014 Oulu, Finland

${ }^{e}$ Delft University of Technology, Department of Chemical Engineering, Julianalaan 136, 2628 BL Delft, the Netherlands

${ }^{*}$ Corresponding author. Tel.: +358 405885904

E-mail address: mirja.illikainen@oulu.fi (M. Illikainen).

Highlights:

- Heavy metal containing FBC fly ashes as artificial aggregate precursor

- Lightweight aggregates with satisfactory physical properties were obtained

- Selectively soluble $\mathrm{SiO}_{2}$ and $\mathrm{Al}_{2} \mathrm{O}_{3}$ had major effect on the aggregate strength

- Barium was effectively immobilized 


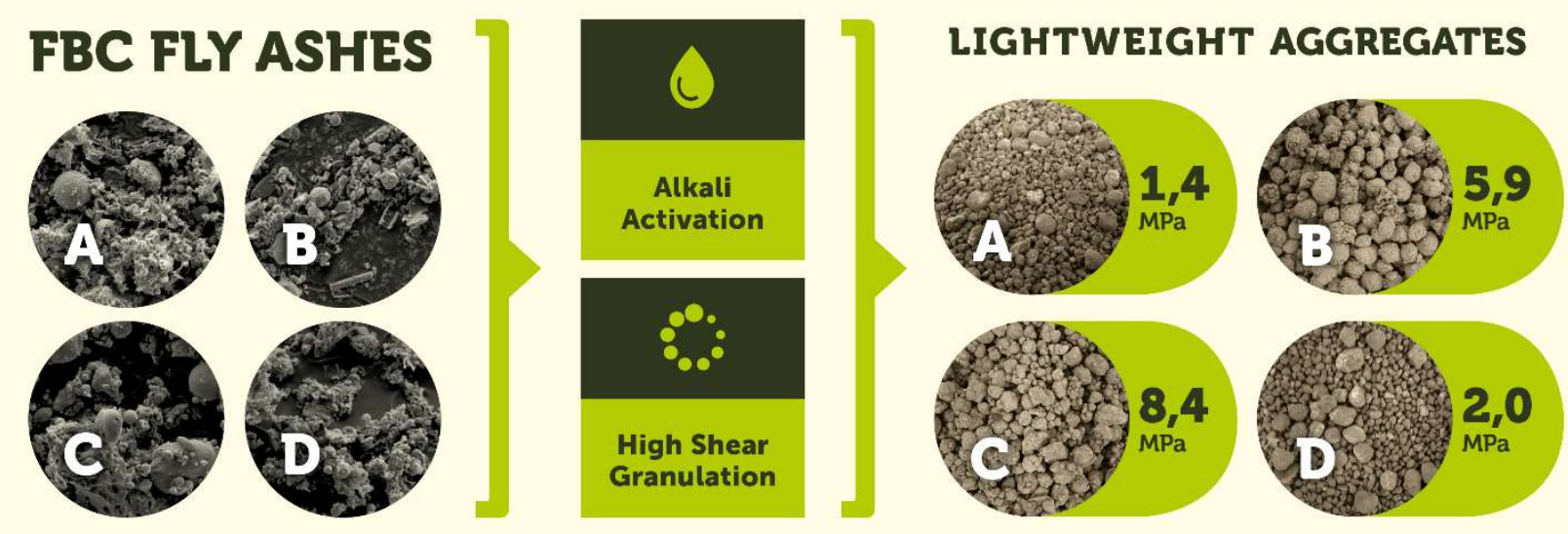

\begin{abstract}
The increasing amount of fluidized bed combustion (FBC) ash is putting pressure on researchers to invent novel methods for utilizing the ash. The low reactivity and heavy metal content constrict the use of FBC ash in the same way as coal ash from pulverized combustion. Four FBC fly ashes from different power plants were granulated with sodium silicate solution in order to produce artificial aggregates. All aggregates matched the definition for lightweight aggregate according to the EN 13055-1 standard. The strongest aggregates were produced from fly ashes that had the highest Xray amorphous material content and the highest amount of selectively soluble $\mathrm{SiO}_{2}$ and $\mathrm{Al}_{2} \mathrm{O}_{3}$. However, the same leaching problem (leaching of the anionic species) as with coal fly ashes was observed with the FBC fly ashes. The simultaneous high shear granulation and alkali activation of FBC ashes showed that artificial aggregates with satisfactory physical properties, such as density and strength, can be obtained even from low-reactive fly ashes that contain heavy metals.
\end{abstract}

Keywords:

Alkali activation; Fluidised bed combustion; Fly ash; Heavy metal; Lightweight aggregate; Granulation

\title{
1. Introduction
}


The European Union's 20-20-20 policy target [1] encourages the use of biomass and waste in energy production. Biomass is sustainable because it takes up a large amount of carbon dioxide during its lifetime [2]. Biomass is often co-combusted with peat or waste materials in fluidized bed combustion (FBC) boilers. The combustion temperature is lower in $\mathrm{FBC}$ techniques $\left(800-900{ }^{\circ} \mathrm{C}\right)$ than in pulverized coal-firing boilers $\left(>1400{ }^{\circ} \mathrm{C}\right)$, which makes it possible to reduce $\mathrm{NO}_{\mathrm{x}}$ and $\mathrm{SO}_{2}$ emissions in flue gas. The stable combustion condition in FBC enables the use of various solid fuels.

Due to the lower combustion temperature, variations in fuel, and possible use of desulphurization sorbents, FBC ashes have significantly different physical, chemical, and mineralogical composition compared to coal ash. The lower content of the glassy phases and the heavy metal content originating from the fuel make the utilization of $\mathrm{FBC}$ ashes challenging and are the reason why most is still deposited in landfills. Therefore, novel solutions for using FBC ash are needed.

Alkali activation as a waste utilization method is rapidly increasing. In alkali activation, aluminum- and silicon-containing solid precursors are dissolved in an alkaline solution to produce a three-dimensional structure consisting of $\mathrm{AlO}_{4}$ and $\mathrm{SiO}_{4}$ units. Often, calcium also participates in the formation of alumino-silicate structures. One beneficial property of alkali-activated materials (AAMs) is the potential to immobilize heavy metals [3-9]. Studies on coal fly ash as alkali activation precursors are numerous. However, studies on alkali activation of FBC fly ashes are much less abundant [10-14].

As FBC ashes have lower glassy phase content and thus lower reactivity than coal ashes, it is unlikely that high-strength products such as alkali-activated cements or concretes could be manufactured from FBC ashes. Instead, manufacturing artificial aggregates from these ashes might be a better solution. The utilization of ash as a precursor for artificial aggregates is economically and ecologically sound because natural raw materials are saved, quarrying activities that damage the 
environment are prevented, and waste is recycled into new products. Artificial aggregates can be used in civil engineering applications and with concrete to replace natural aggregates.

There are two common methods for producing artificial aggregates: cold-bonding granulation with a cementitious binder or high-temperature sintering. The second method has been studied and utilized, but it has a downside since it has high energy consumption and certain wastes are unsuitable for vitrification and sintering. Recently, artificial aggregates have been prepared by granulation of powder wastes with cementitious binders [15-19]. The use of alkali activators as a binder in the granulation process has shown promising results $[14,20]$, but to produce physically and chemically stable products from waste, the raw materials must be carefully characterized.

This study utilizes four FBC fly ashes with high heavy metal content to manufacture alkaliactivated aggregates. The aggregates are produced by a combined high shear granulation-alkali activation process. The fly ashes are thoroughly characterized in order to define the most important properties that influence their performance as aggregates. The alkali-activated aggregates are analyzed physically and mineralogically, and the environmental impact and their potential in civil engineering are considered.

\section{Material and methods}

\subsection{Materials}

The four FBC fly ashes chosen for this study were obtained from circulating and bubbling fluidized bed combustion boilers from different power plants (Table 1). The fly ash samples were collected from electrostatic precipitator (ESP) units or from silos. Two of the fly ashes (A and D) were from the ESP-C, which collects the finest fraction of the fly ash and contains most of the heavy metals $[21,22]$. The other two fly ashes (B and C) were collected from silos, which means that the samples contained fractions from all of the precipitator units. The alkali activator used in 
this study was sodium silicate solution (Zeopol@ 25) with a $\mathrm{SiO}_{2} / \mathrm{Na}_{2} \mathrm{O}$ molar ratio of 2.5 , $\mathrm{pH}$ of 12.5 , and water content of approximately $66 \mathrm{wt} \%$.

\subsection{Methods}

The content of the main chemical components of the fly ashes was determined with Omnian PANanalytical Axios Max 4 kV X-ray fluorescence (XRF) from a melt-fused tablet. The melt-fused tablet was produced from $1.5 \mathrm{~g}$ of fly ash melted at $1150{ }^{\circ} \mathrm{C}$ with $7.5 \mathrm{~g}$ of X-ray Flux Type 66:34 $\left(66 \% \mathrm{Li}_{2} \mathrm{~B}_{4} \mathrm{O}_{7}\right.$ and $\left.34 \% \mathrm{LiBO}_{2}\right)$. The trace element concentrations in the fly ashes were characterized by microwave-assisted wet digestion using a 3:1 mixture of $\mathrm{HNO}_{3}$ and $\mathrm{HCl}$ for $0.5 \mathrm{~g}$ of fly ash, and determination was made using an inductively coupled, plasma-optical emission spectrometer (ICP-OES; Thermo Electron IRIS Intrepid II XDL Duo, Thermo Scientific). Each sample was measured twice. The solubility of selectively soluble $\mathrm{SiO}_{2}, \mathrm{Al}_{2} \mathrm{O}_{3}, \mathrm{CaO}$, and $\mathrm{Fe}_{2} \mathrm{O}_{3}$ to a solution consisting of ethylenediaminetetraacetic acid (EDTA, $\mathrm{C}_{10} \mathrm{H}_{14} \mathrm{~N}_{2} \mathrm{Na}_{2} \mathrm{O}_{8} * 2 \mathrm{H}_{2} \mathrm{O}$ ) and triethanolamine (TEA, $\mathrm{C}_{6} \mathrm{H}_{15} \mathrm{NO}_{3}$ ) solutions with $\mathrm{pH}$ adjusted to $11.6 \pm 0.1$ with the addition of $\mathrm{NaOH}$ was determined [23-25]. The soluble content concentration was determined using the inductively coupled plasma technique. The free $\mathrm{CaO}$ content was determined using the methodology described in [26]. The free calcium oxide describes the dissolved amount of $\mathrm{CaO}$ in a specified mixture of butanoic acid, 3-oxo-ethyl ester, and butan-2-ol during $3 \mathrm{~h}$ boiling time.

The particle size distributions of the fly ashes were determined with a Beckman Coulter LS 13320 using the Fraunhofer model and the wet procedure reported as a volumetric median size ( $\mathrm{d}_{10}$, $\mathrm{d}_{50}$, and $\mathrm{d}_{90}$ ). The specific surface area was determined with ASAP 2020 Micrometrics and was based on the physical adsorption of gas molecules on a solid surface. The results were reported in the form of a BET isotherm. Moisture- $\%$, loss-on-ignition $\left(525^{\circ} \mathrm{C}\right.$ and $\left.950{ }^{\circ} \mathrm{C}\right)$, and $\mathrm{CaCO}_{3}$ content were determined using thermo-gravimetric analysis equipment (PrepAsh, Precisa). 
The fly ashes were granulated with a high shear granulator (Eirich R01) in a process described [27]. A granulator drum spun clockwise at a speed of $170 \mathrm{rpm}$ in a $10^{\circ}$ tilt angle. Inside the drum was an impeller (10 cm diameter) spinning counter-clockwise at a speed of $1200 \mathrm{rpm}$. For each fly ash, a suitable liquid-solid ratio was determined in order to obtain 2-4 mm granules. In short, the granulation process was employed as follows: 1) Dry fly ashes were weighed, mixed, and added to the drum. 2) The impeller and drum were switched on, and approximately $15 \mathrm{~g}$ of sodium silicate solution was added to prevent dusting. 3) Sodium silicate was added by drops until the desired granule size was achieved. Each alkali-activated fly ash granule batch was sealed in air-tight plastic bags, and stored under ambient conditions for 28 days.

Water absorption, dry particle density, and apparent density were determined with the standard [28], and the loose bulk density was determined with the standard [29]. The force required to break granules that were $5 \mathrm{~mm}$ in diameter was measured with a Zwick, Z100 Roell testing machine. The granules were placed between steel plates and loaded under a constant deformation rate of 0.01 $\mathrm{mm} / \mathrm{s}$. At least five granules from each batch were measured.

A leaching test [30] was used to determine the amount of leachable hazardous components in the fly ashes and the alkali-activated aggregates. Deviating from the standard, a sample size of 17.5 $\mathrm{g}$ was used instead of $175 \mathrm{~g}$, and the filter paper retention size was $1 \mu \mathrm{m}$ instead of $0.45 \mu \mathrm{m}$. Duplicate samples of the fly ashes and alkali-activated aggregates were analyzed, and the averages were calculated. Conductivity and $\mathrm{pH}$ measurements were conducted with the Denver Instrument model 50 .

The crystalline phases of the powdered samples were identified with a Siemens 5000 X-ray diffractometer. The step interval, integration time, and angle interval used were $0.04^{\circ}, 4 \mathrm{~s}$, and $10-$ $70^{\circ}$, respectively.

\section{Results and discussion}




\subsection{Fly ash characterization}

Table 1 shows the main chemical components and physical properties of the fly ashes. The fly ash samples displayed a large variation in chemical composition. All samples contained a significant amount of calcium, which is typical for bio fly ashes [31] (it originates from the organic matrix of the fuel). Sludge from the paper industry (fly ash C) has the highest calcium content. The combined amount of silica and alumina, which are the most important elements in alkali activation, was above $50 \mathrm{wt} \%$ only for sample B. This predicts low strength for the alkali-activated materials, but the strength depends also on the soluble fraction of these elements. The fly ash also contained significant but highly variable amounts of $\mathrm{Fe}_{2} \mathrm{O}_{3}$. The selectively soluble leaching test showed that fly ash $\mathrm{C}$ had the highest amount of soluble $\mathrm{SiO}_{2}$ and $\mathrm{Al}_{2} \mathrm{O}_{3}$. High amounts of selectively soluble $\mathrm{CaO}$ were determined for all samples. Sample B had been wetted before storing in the silo, which explains the high moisture content. Fly ash D showed a gain in mass at $950{ }^{\circ} \mathrm{C}$ indicating the oxidation of some component. There was a large variation in the surface area of the fly ashes and particle size distribution of the fly ash samples. Fly ashes A and D had the smallest particles as these samples contained only the fraction from the ESP-C. Fly ashes B and C had the largest particles as these samples also contained fractions from ESP-A and ESP-B. Sample B had the largest surface area and sample $\mathrm{C}$ the smallest. Due to the high free $\mathrm{CaO}$ content, the samples showed high $\mathrm{pH}$ values when suspended in water. 


\section{Table 1}

Characterization of the FBC fly ashes.

Fly ash sample

A

B

C

D

\begin{tabular}{|c|c|c|c|c|}
\hline Combustion technique & $\begin{array}{l}\text { Circulating } \\
\text { fluidized bed } \\
\text { combustion } \\
\text { (CFBC) }\end{array}$ & $\begin{array}{l}\text { Bubbling } \\
\text { fluidized bed } \\
\text { combustion } \\
\text { (BFBC) }\end{array}$ & $\begin{array}{l}\text { Bubbling } \\
\text { fluidized bed } \\
\text { combustion } \\
\text { (BFBC) }\end{array}$ & $\begin{array}{l}\text { Bubbling } \\
\text { fluidized bed } \\
\text { combustion } \\
\text { (BFBC) }\end{array}$ \\
\hline Fuel & Peat & $\begin{array}{l}\text { Peat } 20 \% \text {, Bark } \\
20 \% \text {, Forest } \\
\text { residuals } 50 \% \text {, } \\
\text { Biosludge } 10 \%\end{array}$ & $\begin{array}{l}\text { Wood } 42 \%, \\
\text { Sludge } 54 \% \text {, } \\
\text { Plastic } \\
\text { rejects } 4 \%\end{array}$ & $\begin{array}{l}\text { Wood } 25 \% \text {, } \\
\text { Peat } 75 \%\end{array}$ \\
\hline Sample collection & ESP-C & Silo (ESP-ALL) & ESP-ALL & ESP-C \\
\hline $\mathrm{CaO}, \mathrm{XRF}[\%]$ & 17.7 & 22.3 & 49.3 & 28.0 \\
\hline $\mathrm{SiO}_{2}, \mathrm{XRF}[\%]$ & 30.7 & 42.8 & 27.1 & 17.9 \\
\hline $\mathrm{Al}_{2} \mathrm{O}_{3}, \mathrm{XRF}[\%]$ & 8.7 & 11.4 & 14.1 & 5.9 \\
\hline $\mathrm{Fe}_{2} \mathrm{O}_{3}, \mathrm{XRF}[\%]$ & 23.9 & 5.6 & 1.7 & 7.6 \\
\hline $\mathrm{Na}_{2} \mathrm{O}, \mathrm{XRF}[\%]$ & 1.13 & 2.2 & 0.6 & 1.5 \\
\hline $\mathrm{K}_{2} \mathrm{O}, \mathrm{XRF}[\%]$ & 2.79 & 2.8 & 0.6 & 5.4 \\
\hline $\mathrm{MgO}, \mathrm{XRF}[\%]$ & 3.77 & 4.2 & 3.1 & 5.2 \\
\hline $\mathrm{P}_{2} \mathrm{O}_{5}, \mathrm{XRF}[\%]$ & 4.72 & 2.5 & 0.3 & 4.5 \\
\hline $\mathrm{TiO}_{2}, \mathrm{XRF}[\%]$ & 0.23 & 0.4 & 0.7 & 0.3 \\
\hline $\mathrm{SO}_{3}, \mathrm{XRF}[\%]$ & 5.18 & 3.4 & 0.8 & 19.7 \\
\hline $\mathrm{Cl}, \mathrm{XRF}[\%]$ & 0.15 & 0.1 & 0.5 & 0.3 \\
\hline Free $\mathrm{CaO}[\%]$ & 0.24 & 2.2 & 6.3 & 2.0 \\
\hline $\mathrm{CaCO}_{3}$ by TGA [\%] & 1.10 & 1 & 4.8 & 0.0 \\
\hline Selectively soluble $\mathrm{CaO}[\%]$ & 4.7 & 14.4 & 36.0 & 25.2 \\
\hline Selectively soluble $\mathrm{SiO}_{2}[\%]$ & 3.4 & 7.0 & 10.1 & 3.8 \\
\hline Selectively soluble $\mathrm{Al}_{2} \mathrm{O}_{3}[\%]$ & 1.0 & 2.0 & 5.5 & 1.9 \\
\hline Selectively soluble $\mathrm{Fe}_{2} \mathrm{O}_{3}[\%]$ & 1.3 & 0.9 & 0.6 & 2.0 \\
\hline Moisture [\%] & 0.2 & 8.7 & 0.03 & 0.0 \\
\hline LOI $525{ }^{\circ} \mathrm{C}[\%]$ & 0.7 & 3.1 & -0.1 & 0.1 \\
\hline LOI $950{ }^{\circ} \mathrm{C}[\%]$ & 1.2 & 5.6 & 2 & -2.7 \\
\hline BET surface area $\left[\mathrm{m}^{2} / \mathrm{g}\right]$ & 7.329 & 17.175 & 1.446 & 5.609 \\
\hline $\mathrm{d}_{10}[\mu \mathrm{m}]$ & 1.2 & 19.3 & 23.1 & 1.2 \\
\hline $\mathrm{d}_{50}[\mu \mathrm{m}]$ & 9.4 & 61.9 & 226.4 & 8.1 \\
\hline $\mathrm{d}_{90}[\mu \mathrm{m}]$ & 29.7 & 305.1 & 525.0 & 22.0 \\
\hline $\mathrm{pH}$ & 11.0 & 12 & 12.3 & 12.0 \\
\hline
\end{tabular}


Table 2 shows the trace element content of the fly ashes. All samples had a significant heavy metal content. Fly ashes A and D were from ESP-C, which collects the finest fly ash fraction, which has the highest heavy metal content. In addition, the heavy metal content of fly ashes B and C was high because the fuel combusted in those power plants contained waste materials. The $\mathrm{Zn}$ content in particular was high for all samples. In addition, significant amounts of $\mathrm{Pb}$ and $\mathrm{Cu}$ were determined.

\section{Table 2}

Trace element content of the fly ash samples.

\begin{tabular}{ccccc} 
Fly ash sample & A & B & C & D \\
\hline Ti, ICP $[\mathrm{mg} / \mathrm{kg}]$ & 500 & 1300 & 1400 & 880 \\
S, ICP [mg/kg] & 20600 & 12200 & 2900 & 50300 \\
Ba, ICP $[\mathrm{mg} / \mathrm{kg}]$ & 1800 & 1200 & 800 & 2500 \\
$\mathrm{Mn}, \mathrm{ICP}[\mathrm{mg} / \mathrm{kg}]$ & 7100 & 5800 & 300 & 12400 \\
$\mathrm{As}, \mathrm{ICP}[\mathrm{mg} / \mathrm{kg}]$ & 62 & 10 & 9 & 160 \\
$\mathrm{Cd}, \mathrm{ICP}[\mathrm{mg} / \mathrm{kg}]$ & 7.2 & 3.6 & 2.5 & 13.0 \\
$\mathrm{Cr}, \mathrm{ICP}[\mathrm{mg} / \mathrm{kg}]$ & 110 & 72 & 77 & 93 \\
$\mathrm{Cu}, \mathrm{ICP}[\mathrm{mg} / \mathrm{kg}]$ & 160 & 100 & 380 & 170 \\
$\mathrm{Hg}, \mathrm{CVAAS}[\mathrm{mg} / \mathrm{kg}]$ & 1.9 & 0.2 & 0.2 & 1.0 \\
$\mathrm{Ni}, \mathrm{ICP}[\mathrm{mg} / \mathrm{kg}]$ & 87 & 65 & 38 & 71 \\
$\mathrm{~Pb}, \mathrm{ICP}[\mathrm{mg} / \mathrm{kg}]$ & 170 & 35 & 460 & 130 \\
$\mathrm{Zn}, \mathrm{ICP}[\mathrm{mg} / \mathrm{kg}]$ & 950 & 890 & 1440 & 2580 \\
$\mathrm{~B}, \mathrm{ICP}[\mathrm{mg} / \mathrm{kg}]$ & 130 & 160 & 56 & 330 \\
$\mathrm{Be}, \mathrm{ICP}[\mathrm{mg} / \mathrm{kg}]$ & 1.1 & $<1$ & 1.0 & 1.2 \\
$\mathrm{Co}, \mathrm{ICP}[\mathrm{mg} / \mathrm{kg}]$ & 30 & 12 & 7 & 20 \\
$\mathrm{Mo}, \mathrm{ICP}[\mathrm{mg} / \mathrm{kg}]$ & 7.8 & 9.8 & 1.3 & 51.0 \\
$\mathrm{Sb}, \mathrm{ICP}[\mathrm{mg} / \mathrm{kg}]$ & $<3$ & $<3$ & $<3$ & 5.2 \\
$\mathrm{Se}, \mathrm{ICP}[\mathrm{mg} / \mathrm{kg}]$ & 6.1 & 3.5 & $<3$ & 7.7 \\
$\mathrm{Sn}, \mathrm{ICP}[\mathrm{mg} / \mathrm{kg}]$ & $<3$ & $<3$ & 11.0 & 5.9 \\
$\mathrm{~V}, \mathrm{ICP}[\mathrm{mg} / \mathrm{kg}]$ & 110 & 48 & 20 & 150 \\
\hline
\end{tabular}

\subsection{Physical properties of the alkali-activated aggregates}

Table 3 presents the consumed amount of sodium silicate, water absorption, loose bulk density, apparent and dry density, and crushing strength of the alkali-activated aggregates. The amount of sodium silicate depends on the operation window (liquid-solid ratio) of the granulation $[32,33]$. Samples A and C required significantly more liquid in order to produce desired size granules. The water absorption of the aggregates varied between $17.8 \%$ and $35.6 \%$. The densities easily surpassed 
the lightweight aggregate requirement in the standard [34] loose bulk density $<1.20 \mathrm{~g} / \mathrm{cm}^{3}$ or dry density $<2.00 \mathrm{~g} / \mathrm{cm}^{3}$ ). The highest crushing strength was observed for fly ash sample $\mathrm{C}$ with a 151 $\mathrm{N}$ crushing force. The crushing force correlated with the selectively soluble $\mathrm{SiO}_{2}$ and $\mathrm{Al}_{2} \mathrm{O}_{3}$ (Fig. 1). This interpretation has its drawback as the $\mathrm{pH}$ in the selectively soluble method is 11.6 , and the $\mathrm{pH}$ of the alkali activator was 12.5 . The soluble $\mathrm{CaO}$ may also change the $\mathrm{pH}$ during the process. Thus, the conditions were not the same, and the amount of soluble components was most likely different. In addition, the method is designed to determine the degree of reaction of fly ash in cement systems and thus is not directly applicable for alkali-activated systems [23-25]. Therefore, the results for the selectively soluble method should be taken only as an indication instead of as a quantitative measure to determine the quantity of reactive components in the fly ashes. Nevertheless, the correlation between the crushing strength and particularly the selectively soluble $\mathrm{SiO}_{2}$ is notable.

\section{Table 3}

Water absorption, apparent, dry and loose bulk dry density, and crushing strength of the alkaliactivated aggregates. The crushing strength is the average of at least five granules, and the error represents the confidence interval for means at the $95 \%$ confidence level.

\begin{tabular}{lcccc}
\multicolumn{1}{r}{ Alkali-activated aggregate } & A & B & C & D \\
\hline Sodium silicate $(\mathrm{g} / 200 \mathrm{~g}$ of fly & 200 & 120.5 & 187.6 & 121.2 \\
ash) & 17.8 & 32.1 & 22.5 & 35.6 \\
Water absorption [\%] & 2.82 & 2.81 & 2.91 & 2.96 \\
Apparent density [g/cm $\left.{ }^{3}\right]$ & 1.64 & 1.37 & 1.60 & 1.02 \\
Dry density $\left[\mathrm{g} / \mathrm{cm}^{3}\right]$ & 0.97 & 0.68 & 0.88 & 0.61 \\
Loose bulk density $\left[\mathrm{g} / \mathrm{cm}^{3}\right]$ & $28 \pm 8$ & $116 \pm 16$ & $151 \pm 33$ & $40 \pm 12$ \\
Crushing strength $[\mathrm{N}]$ & & &
\end{tabular}

The aggregate strength was also found to correlate with the particle size distribution of the fly ashes. Larger fly ash particles yielded higher strength. However, in this case, the increase in strength more likely originated from the higher amount of reactive material (see Section 3.4). In any event, the primary particle size is well-known to affect the aggregate size and strength [35]. But instead of the large particle size, wider particle size distribution can yield better results in 
granulation as it enhances the packing of the particles. The particle size distribution width $\left(\mathrm{d}_{90}-\mathrm{d}_{10}\right)$ was $285.5 \mu \mathrm{m}$ and $501.9 \mu \mathrm{m}$ for fly ashes B and C, respectively, whereas the width was only 28.5 $\mu \mathrm{m}$ and $20.8 \mu \mathrm{m}$ for fly ashes A and D, respectively.

It would be natural to presume that a larger surface area and smaller particles would result in a higher amount of liquid required in the granulation process. However, no correlation was found. This suggests that the reaction between the fly ash particles and the alkali activator starts instantly thus changing the available liquid in the granulation, although the fly ash surface area also affects to the process.

The crushing strength results were compared to those in the literature by calculating the compressive strength with Eq. (1) and Eq. (2):

$$
\begin{aligned}
& S=\frac{(2.8 * \mathrm{~F})}{\pi * d^{2}} \quad[36], \\
& S=\frac{\mathrm{F}}{\frac{\pi}{4} * d^{2}}
\end{aligned}
$$

where $\mathrm{F}$ is the fracture load $(\mathrm{N})$, and $\mathrm{d}$ is the average granule diameter ( $5 \mathrm{~mm}$ in this study). The conversion from newtons to megapascals with Eq. (1) gives compressive strength of 1.0 MPa, 4.1 $\mathrm{MPa}, 5.8 \mathrm{MPa}$, and 1.4 MPa for the fly ash aggregates A, B, C, and D, respectively. Eq. (2) gives slightly higher compressive strengths (1.4 MPa, 5.9 MPa, 8.4 MPa, and 2.0 MPa) because the coefficient is larger in the equation. The compressive strength results are in line with those in previous studies $[14,27]$ in which artificial aggregates were prepared with the same method from FBC peat-wood fly ash and FBC recovered fuel-biofuel fly ash. In studies conducted by Bui et al. [18], Cioffi et al. [14], Colangelo et al. [15], Ferone et al. [16], and González-Corrochano et al. [38-40], artificial aggregates were prepared from several different precursors (class F fly ash, rice husk fly ash, ground granulated blast furnace slag, mining and industrial wastes, washing aggregate sludge, used motor oil, and other wastes) with a cement- or alkali activator-based pelletization process or by sintering in a rotary kiln. The results show that the aggregate strengths are very 
similar in all studies although the raw materials and the aggregates preparation methods are different. [18] reported that the compressive strength of lightweight expanded clay aggregate Leca ${ }^{\circledR}$ was between 0.7 and $4.5 \mathrm{MPa}$, depending on the granule size. It shows that a sufficient mechanical performance for lightweight aggregates can be easily obtained even from waste materials prepared by the granulation and pelletization processes and could replace it in the civil engineering applications if leaching of hazardous components can be kept below the threshold values stipulated by the standards used.

\subsection{Leachable components from fly ashes and alkali-activated aggregates}

Leachable components and the legal leaching limits from fly ashes and alkali-activated aggregates are presented in Tables 4 and 5. The deviation from the standard [30] amount of leachate in the first step (liquid-solid ratio of 2) was too low to determine the hazardous component content. Instead, the leachate sample slurry was transferred immediately to the second step. The results are shown with a total liquid-solid ratio of 10 . The hazardous leachable elements from the fly ashes were $\mathrm{Ba}, \mathrm{Cr}, \mathrm{Mo}, \mathrm{Se}, \mathrm{Cl}$, and $\mathrm{SO}_{4}$.

After alkali activation, lower leaching was observed for $\mathrm{Ba}$ and $\mathrm{Cl}$ in all samples. Especially the immobilization of $\mathrm{Ba}$ in fly ash $\mathrm{C}$ was significant $(95.7 \mathrm{mg} / \mathrm{kg} \geq 0.07 \mathrm{mg} / \mathrm{kg})$. However, higher leaching was observed for $\mathrm{As}, \mathrm{Cu}$, and V. For samples $\mathrm{B}$ and $\mathrm{C}$, the leaching of $\mathrm{Cr}$, Mo, $\mathrm{Zn}$, and $\mathrm{SO}_{4}$ was higher after alkali activation. Sample D was different from the others since decreased leaching was observed for $\mathrm{Cr}, \mathrm{Cu}$, and Mo. Thus, this sample had the most positive performance in alkali activation in the environmental sense. In addition, the conductivity was lower after alkali activation for sample D; thus, the total amount of leachable ions decreased.

Increased leaching of As, $\mathrm{Cr}, \mathrm{Mo}$, and $\mathrm{V}$ in alkali activation has been observed for coal fly ashes as well $[7,41-43]$ and is explained by the formation of oxyanionic species that are leachable at high $\mathrm{pH}$. However, the $\mathrm{pH}$ of the fly ashes was high even before the alkali activation, which contradicts 
this theory. Similar behavior has been observed $[14,44]$. Apparently, the alkali activator liberates more elements than the leaching solution, and these elements are not bound strongly to the geopolymer matrix because there is no place or need for anions. Thus, these elements will remain loosely bound and therefore leach out easily. The extent of the liberation of the elements is most likely dependent on the FBC fly ash chemistry and morphology, and is not related to the total amount of the element (Table 2). The formation of FBC ash depends mainly on the combustion conditions and fuel $[45,46]$.

Comparing leachable hazardous elements to the limits set in the legislation, most elements are below the limit for paved structures. However, the leachable sulfate exceeds this limit. This problem could be solved by washing the fly ash before experiments in order to remove soluble chlorides and sulfates with the method described by [47]. In addition, the leaching of vanadium exceeds the paved structure limit for all ashes except for fly ash A.

\section{Table 4}

Leachable hazardous components from fly ashes with a liquid-solid ratio of 10 as determined with the standard [30]. The national legal limit for components are shown for covered and paved structures set in [48].

\begin{tabular}{lcccccc}
\multicolumn{1}{c}{ Fly ash sample } & A & B & C & D & $\begin{array}{l}\text { Covered } \\
\text { structure }\end{array}$ & $\begin{array}{l}\text { Paved } \\
\text { structure }\end{array}$ \\
\hline $\mathrm{pH}$ & 9.5 & 12.5 & 12.7 & 12.2 & & \\
$\mathrm{Conductivity}[\mu \mathrm{S} / \mathrm{cm}]$ & 4.3 & 5.5 & 7.2 & 10.9 & & \\
$\mathrm{As}[\mathrm{mg} / \mathrm{kg}]$ & $<0.15$ & $<0.15$ & $<0.15$ & $<0.15$ & 0.5 & 1.5 \\
$\mathrm{Ba}[\mathrm{mg} / \mathrm{kg}]$ & 1.6 & 2.6 & 95.7 & 1.5 & 20 & 60 \\
$\mathrm{Cd}[\mathrm{mg} / \mathrm{kg}]$ & $<0.02$ & $<0.02$ & $<0.02$ & $<0.02$ & 0.04 & 0.04 \\
$\mathrm{Cr}[\mathrm{mg} / \mathrm{kg}]$ & 1.1 & 0.4 & $<0.1$ & 5.7 & 0.5 & 3 \\
$\mathrm{Cu}[\mathrm{mg} / \mathrm{kg}]$ & $<0.05$ & $<0.05$ & $<0.05$ & 0.06 & 2 & 6 \\
$\mathrm{Mo}[\mathrm{mg} / \mathrm{kg}]$ & 2.70 & 2.62 & 0.06 & 22.54 & 0.5 & 6 \\
$\mathrm{~Pb}[\mathrm{mg} / \mathrm{kg}]$ & $<0.15$ & $<0.15$ & $<0.15$ & $<0.15$ & 0.5 & 1.5 \\
$\mathrm{Ni}[\mathrm{mg} / \mathrm{kg}]$ & $<0.05$ & $<0.05$ & $<0.05$ & $<0.05$ & 0.4 & 1.2 \\
$\mathrm{~V}[\mathrm{mg} / \mathrm{kg}]$ & $<0.05$ & $<0.05$ & $<0.05$ & $<0.05$ & 2 & 3 \\
$\mathrm{Zn}[\mathrm{mg} / \mathrm{kg}]$ & $<0.1$ & $<0.1$ & $<0.1$ & $<0.1$ & 4 & 12 \\
$\mathrm{Cl}[\mathrm{mg} / \mathrm{kg}]$ & 2087 & 617 & 951 & 4822 & 800 & 2400
\end{tabular}




\begin{tabular}{lcccccc}
$\mathrm{SO}_{4}[\mathrm{mg} / \mathrm{kg}]$ & 25867 & 471 & 42 & 55720 & 1000 & 10000 \\
$\mathrm{~F}[\mathrm{mg} / \mathrm{kg}]$ & $<10$ & $<10$ & 17 & $<10$ & 10 & 50 \\
$\mathrm{Sb}[\mathrm{mg} / \mathrm{kg}]$ & $<0.15$ & $<0.15$ & $<0.15$ & $<0.15$ & 0.06 & 0.18 \\
$\mathrm{Se}[\mathrm{mg} / \mathrm{kg}]$ & 0.9 & $<0.15$ & $<0.15$ & 0.9 & 0.1 & 0.5 \\
\hline
\end{tabular}

\section{Table 5}

Leachable hazardous components from alkali-activated aggregates with a liquid-solid ratio of 10 as determined with the standard [30]. The national legal limits for the components are shown for covered and paved structures set in [48]. If the values increased more than double compared to the values in Table 4, they are bolded and in italics. If the values decreased more than half compared to the values in Table 4, they are underlined.

\begin{tabular}{lcccccc} 
Alkali-activated aggregate & $\mathrm{A}$ & $\mathrm{B}$ & $\mathrm{C}$ & $\mathrm{D}$ & $\begin{array}{c}\text { Covered } \\
\text { structure }\end{array}$ & $\begin{array}{c}\text { Paved } \\
\text { structure }\end{array}$ \\
\hline $\mathrm{pH}$ & 11.2 & 12.1 & 12.7 & 11.6 & & \\
$\mathrm{Conductivity}[\mu \mathrm{S} / \mathrm{cm}]$ & 6.4 & 6.1 & 10.2 & $\underline{7.5}$ & & \\
$\mathrm{As}[\mathrm{mg} / \mathrm{kg}]$ & $\mathbf{2 . 2}$ & $\mathbf{0 . 8}$ & $\mathbf{2 . 4}$ & $\mathbf{1 . 4}$ & 0.5 & 1.5 \\
$\mathrm{Ba}[\mathrm{mg} / \mathrm{kg}]$ & $\underline{0.25}$ & $\underline{0.54}$ & $\underline{0.07}$ & $\underline{0.47}$ & 20 & 60 \\
$\mathrm{Cd}[\mathrm{mg} / \mathrm{kg}]$ & 0.06 & 0.03 & $<0.02$ & $<0.02$ & 0.04 & 0.04 \\
$\mathrm{Cr}[\mathrm{mg} / \mathrm{kg}]$ & 0.6 & $\mathbf{1 . 5}$ & $\mathbf{1 1 . 3}$ & $\underline{1.5}$ & 0.5 & 3 \\
$\mathrm{Cu}[\mathrm{mg} / \mathrm{kg}]$ & $\mathbf{0 . 1 1}$ & $\mathbf{0 . 1 6}$ & $\mathbf{0 . 1 6}$ & 0.05 & 2 & 6 \\
$\mathrm{Mo}[\mathrm{mg} / \mathrm{kg}]$ & $\underline{0.89}$ & 2.69 & $\mathbf{1 . 0 8}$ & $\underline{6.75}$ & 0.5 & 6 \\
$\mathrm{~Pb}[\mathrm{mg} / \mathrm{kg}]$ & $\mathbf{1 . 2 5}$ & $\mathbf{0 . 4 0}$ & $<0.15$ & $<0.15$ & 0.5 & 1.5 \\
$\mathrm{Ni}[\mathrm{mg} / \mathrm{kg}]$ & 0.08 & $<0.05$ & $<0.05$ & $<0.05$ & 0.4 & 1.2 \\
$\mathrm{~V}[\mathrm{mg} / \mathrm{kg}]$ & $\mathbf{2 . 1 0}$ & $\mathbf{3 . 1 3}$ & $\mathbf{3 . 1 3}$ & 4.54 & 2 & 3 \\
$\mathrm{Zn}[\mathrm{mg} / \mathrm{kg}]$ & $<0.1$ & $\mathbf{0 . 2 5}$ & 0.11 & $<0.1$ & 4 & 12 \\
$\mathrm{Cl}[\mathrm{mg} / \mathrm{kg}]$ & $\underline{532}$ & $\underline{256}$ & 814 & $\underline{1072}$ & 800 & 2400 \\
$\mathrm{SO} 4[\mathrm{mg} / \mathrm{kg}]$ & $\underline{11931}$ & $\mathbf{1 6 9 8 4}$ & $\mathbf{4 9 3 3}$ & 34886 & 1000 & 10000 \\
$\mathrm{~F}[\mathrm{mg} / \mathrm{kg}]$ & $<10$ & $<10$ & $<10$ & 10 & 10 & 50 \\
$\mathrm{Sb}[\mathrm{mg} / \mathrm{kg}]$ & $<0.15$ & $<0.15$ & $\mathbf{0 . 4 7}$ & $<0.15$ & 0.06 & 0.18 \\
$\mathrm{Se}[\mathrm{mg} / \mathrm{kg}]$ & 1.7 & $\mathbf{1 . 0}$ & $<0.15$ & 0.4 & 0.1 & 0.5 \\
\hline
\end{tabular}

\subsection{Mineralogical characterization}

Fig. 2 shows the X-ray diffractograms of fly ashes A-D and their alkali-activated aggregates. One immediate observation is the high amount of crystalline phases present. This is due to the low 
combustion temperature in which most of the inorganic minerals will not melt. In pulverized coalfired combustion, the temperature is above the melting point of most minerals present, which yields a higher glassy phase content upon quenching and higher reactivity in alkali activation.

According to the XRD analysis, fly ash A contained mainly magnesioferrite $\left((\mathrm{Mg}, \mathrm{Fe}) \mathrm{Fe}_{2} \mathrm{O}_{4}\right)$ quartz $\left(\mathrm{SiO}_{2}\right)$, albite $\left(\mathrm{NaAlSi}_{3} \mathrm{O}_{8}\right)$, anhydrite $\left(\mathrm{CaSO}_{4}\right)$, and hematite $\left(\mathrm{Fe}_{2} \mathrm{O}_{3}\right)$, with probably some brownmillerite $\left(\mathrm{Ca}_{2}(\mathrm{Fe}, \mathrm{Al})_{2} \mathrm{O}_{5}\right)$, hydroxylapatite $\left(\mathrm{Ca}_{5}\left(\mathrm{PO}_{4}\right)_{3}(\mathrm{OH})\right)$, microcline $\left(\mathrm{KAlSi}_{3} \mathrm{O}_{8}\right)$, calcite $\left(\mathrm{CaCO}_{3}\right)$, gehlenite $\left(\mathrm{Ca}_{2} \mathrm{Al}_{2} \mathrm{SiO}_{7}\right)$, and lime $(\mathrm{CaO})$ as the crystalline phases. During alkali activation (Fig. 2a), most of the anhydrite and hydroxylapatite phases disappeared. The proportion of the amorphous phases increased, and new crystalline phases were not formed.

Fly ash B was composed mostly of quartz, anorthoclase ((Na,K)AlSi $\left.\mathrm{O}_{8}\right)$, albite, magnesioferrite, calcite, and anhydrite with maybe some hydroxylapatite, microcline, cristobalite $\left(\mathrm{SiO}_{2}\right)$, åkermanite $\left(\mathrm{Ca}_{2} \mathrm{Mg}\left(\mathrm{Si}_{2} \mathrm{O}_{7}\right)\right)$, ettringite $\left(\mathrm{Ca}_{6} \mathrm{Al}_{2}\left(\mathrm{SO}_{4}\right)_{3}(\mathrm{OH})_{12} \cdot 26 \mathrm{H}_{2} \mathrm{O}\right)$, ferrohornblende $\left(\mathrm{Ca}_{2} \mathrm{Fe}^{2+}{ }_{4} \mathrm{Al}_{0.75} \mathrm{Fe}^{3+}{ }_{0.25}\left(\mathrm{Si}_{7} \mathrm{AlO}_{22}\right)(\mathrm{OH})_{2}\right)$, portlandite $\left(\mathrm{Ca}(\mathrm{OH})_{2}\right)$, lime, and calcium aluminium iron carbonate hydroxide hydrate $\left(\mathrm{Ca}_{8} \mathrm{Al}_{2} \mathrm{Fe}_{2} \mathrm{O}_{12} \mathrm{CO}_{3}(\mathrm{OH})_{2} \cdot 22 \mathrm{H}_{2} \mathrm{O}\right)$ as the crystalline phases. The presence of ettringite and portlandite is due to the wetting of the ash during storage. During alkali activation (Fig. 2b), ettringite, portlandite, and calcium aluminum iron carbonate hydroxide hydrate disappeared. The disappearance of anorthoclase was probably not due to the reaction during alkali activation. There were a few larger-than-average anorthoclase grains, and they just accidentally were not captured in the particular XRD sample.

Fly ash $\mathrm{C}$ contained gehlenite, quartz, larnite $\left(\mathrm{Ca}_{2} \mathrm{SiO}_{4}\right)$, lime, mayenite $\left(\mathrm{Ca}_{12} \mathrm{Al}_{14} \mathrm{O}_{33}\right)$, calcite, brownmillerite, albite, and anhydrite as crystalline phases. Alkali activation (Fig. 2c) consumed most of the larnite, mayenite, anhydrite, and lime phases. Based on the XRD analysis, instead of new crystalline phases, only amorphous material was formed.

Besides of anhydrite, gehlenite, quartz, calcite, and srebrodolskite $\left(\mathrm{Ca}_{2} \mathrm{Fe}_{2} \mathrm{O}_{5}\right)$, fly ash D contained some hydroxylapatite, lime, albite, cristobalite, maghemite $\left(\mathrm{Fe}_{2} \mathrm{O}_{3}\right)$, hematite, and 
periclase (MgO) as the minor crystalline phases. During alkali activation (Fig. 2d), practically all of the anhydrite and lime and most of the hydroxylapatite phases disappeared. The proportion of the amorphous phases increased. New crystalline phases were not identified.

The high crushing strength for the aggregates prepared from fly ashes B and C was most likely caused by the higher reactive material content than in fly ashes A and D. The results for the selectively soluble method (Table 1) and XRD (Figure 2) indicated that reactive silicon was mainly present in the amorphous phase. The reactive aluminum and calcium originated from several crystalline phases, but was also likely present in the amorphous phase. As no new phases were identified, the reactive components formed nanocrystalline zeolite-type structures [49] or Na-(Ca)Al-Si-hydrates depending on the amount of calcium available [50].

\section{Conclusions}

The increasing amount of FBC ashes is putting pressure on researchers to invent novel methods for utilizing the ash. Low reactivity and heavy metal content constrict FBC ash utilization as extensively as coal ash from pulverized combustion. In this study, artificial aggregates were prepared from FBC fly ashes by simultaneous granulation and the alkali activation method.

The results of this study show that artificial aggregates with satisfactory physical properties can be obtained even from low-reactive fly ashes that contain heavy metals. The bulk density was between 0.61 and $0.97 \mathrm{~g} / \mathrm{cm}^{3}$, which surpasses the LWA definition (loose bulk density $<1.20$ $\mathrm{g} / \mathrm{cm}^{3}$ ). The water absorption of the artificial aggregates varied from $17.8 \%$ to $35.6 \%$. The crushing strength of a single aggregate up to $8.4 \mathrm{MPa}$ was obtained. The strongest aggregates were produced from fly ashes that had the highest amount of selectively soluble $\mathrm{SiO}_{2}$ and $\mathrm{Al}_{2} \mathrm{O}_{3}$. In addition to the amorphous phase, anhydrite, hydroxyapatite, ettringite, lime, mayenite, larnite, and periclase were reactive phases during alkali activation. The fly ashes contained significant amounts of $\mathrm{Ba}, \mathrm{Pb}$, and $\mathrm{Zn}$, but several other heavy metals were also present. After alkali activation, effective stabilization 
of Ba was observed for all ashes. However, increased leaching was observed especially for anionic heavy metal species.

\section{Acknowledgments}

This work was carried out under the auspices of the GEOPO Project, supported by the Finnish Funding Agency for Technology and Innovation (Tekes) and various companies (Boliden Harjavalta Oy, Ekokem-Palvelu Oy, Fortum Power and Heat Oy, Helen Oy, Jyväskylän Energia Oy, Kemira Chemicals Oy, Valmet Power Oy, Metsä Group, Napapiirin Energia ja Vesi, Stora Enso Oyj, and UPM). The authors would like to thank the Renlund Foundation for its financial support. BSc Tuomas Pöykkö is acknowledged for performing part of the experimental work as a part of his bachelor thesis project. Jarno Karvonen, Elisa Wirkkala, and Jani Österlund are acknowledged for their contributions to the laboratory analyses. The personnel of the Center of Microscopy and Nanotechnology are acknowledged for their contributions to the FESEM and XRD analyses.

\section{References}

1. Europe 2020: EU-wide headline targets for economic growth - European Commission, http://ec.europa.eu/europe2020/europe-2020-in-a-nutshell/targets/index_en.htm.

2. Shearer, C., Yeboah, N., Kurtis, K., Burns, S. eds: Investigation of biomass Co-fired fly ash properties: Characterization and concrete durability performance. In: Sustainable construction materials and technologies: Second International Conference on Sustainable Construction Materials and Technologies, 28-30 June 2010, Ancona, Italy. pp. 1719-29. UWM Center for By-Products Utlilization; Second International Conference on SCMT, Milwaukee, WI; Ancona, Italy (2010).

3. Fernández Pereira, C., Luna, Y., Querol, X., Antenucci, D., Vale, J.: Waste stabilization/solidification of an electric arc furnace dust using fly ash-based geopolymers. Fuel. 88, 1185-1193 (2009).

4. Provis, J.L.: Immobilisation of toxic wastes in geopolymers. In: Geopolymers: Structures, Processing, Properties and Industrial Applications. pp. 421-440 (2009).

5. van Jaarsveld, J.G.S., van Deventer, J.S.J., Lorenzen, L.: The potential use of geopolymeric materials to immobilise toxic metals: Part I. Theory and applications. Miner. Eng. 10, 659-669 (1997).

6. Xu, J.Z., Zhou, Y.L., Chang, Q., Qu, H.Q.: Study on the factors of affecting the immobilization of heavy metals in fly ash-based geopolymers. Mater. Lett. 60, 820-822 (2006). 
7. Zhang, J., Provis, J.L., Feng, D., van Deventer, J.S.J.: Geopolymers for immobilization of Cr6+, Cd2+, and Pb2+. J. Hazard. Mater. 157, 587-598 (2008b).

8. Ponzoni, C., Lancellotti, I., Barbieri, L., Spinella, A., Saladino, M.L., Martino, D.C., Caponetti, E., Armetta, F., Leonelli, C.: Chromium liquid waste inertization in an inorganic alkali activated matrix: Leaching and NMR multinuclear approach. J. Hazard. Mater. 286, 474-483 (2015).

9. Ferone, C., Colangelo, F., Messina, F., Santoro, L., Cioffi, R.: Recycling of Pre-Washed Municipal Solid Waste Incinerator Fly Ash in the Manufacturing of Low Temperature Setting Geopolymer Materials. Materials. 6, 3420-3437 (2013).

10. Chindaprasirt, P., Paisitsrisawat, P., Rattanasak, U.: Strength and resistance to sulfate and sulfuric acid of ground fluidized bed combustion fly ash-silica fume alkali-activated composite. Adv. Powder Technol. 25, 1087-1093 (2014).

11. Chindaprasirt, P., Rattanasak, U.: Utilization of blended fluidized bed combustion (FBC) ash and pulverized coal combustion (PCC) fly ash in geopolymer. Waste Manag. 30, 667-672 (2010).

12. Tyni, S.K., Karppinen, J.A., Tiainen, M.S., Laitinen, R.S.: Preparation and characterization of amorphous aluminosilicate polymers from ash formed in combustion of peat and wood mixtures. J. Non-Cryst. Solids. 387, 94-100 (2014).

13. Tyni, S.K., Yliniemi, Juho, Tiainen, Minna, Laitinen, Risto: Fly ash as precursor for geopolymers. 2012, 171-178 (2012).

14. Yliniemi, J., Pesonen, J., Tiainen, M., Illikainen, M.: Alkali activation of recovered fuelbiofuel fly ash from fluidised-bed combustion: Stabilisation/solidification of heavy metals. Waste Manag. 43, 273-282 (2015).

15. Arslan, H., Baykal, G.: Utilization of fly ash as engineering pellet aggregates. Environ. Geol. 50, 761-770 (2006).

16. Cioffi, R., Colangelo, F., Montagnaro, F., Santoro, L.: Manufacture of artificial aggregate using MSWI bottom ash. Waste Manag. 31, 281-288 (2011).

17. Colangelo, F., Cioffi, R.: Use of Cement Kiln Dust, Blast Furnace Slag and Marble Sludge in the Manufacture of Sustainable Artificial Aggregates by Means of Cold Bonding Pelletization. Materials. 6, 3139-3159 (2013).

18. Ferone, C., Colangelo, F., Messina, F., Iucolano, F., Liguori, B., Cioffi, R.: Coal Combustion Wastes Reuse in Low Energy Artificial Aggregates Manufacturing. Materials. 6, 5000-5015 (2013).

19. Gesoğlu, M., Güneyisi, E., Öz, H.Ö.: Properties of lightweight aggregates produced with coldbonding pelletization of fly ash and ground granulated blast furnace slag. Mater. Struct. 45, 1535-1546 (2012).

20. Bui, L.A., Hwang, C., Chen, C., Lin, K., Hsieh, M.: Manufacture and performance of cold bonded lightweight aggregate using alkaline activators for high performance concrete. Constr. Build. Mater. 35, 1056-1062 (2012).

21. Dahl, O., Nurmesniemi, H., Pöykiö, R., Watkins, G.: Heavy metal concentrations in bottom ash and fly ash fractions from a large-sized (246MW) fluidized bed boiler with respect to their Finnish forest fertilizer limit values. Fuel Process. Technol. 91, 1634-1639 (2010).

22. Dahl, O., Nurmesniemi, H., Pöykiö, R., Watkins, G.: Comparison of the characteristics of bottom ash and fly ash from a medium-size (32 MW) municipal district heating plant incinerating forest residues and peat in a fluidized-bed boiler. Fuel Process. Technol. 90, 871878 (2009).

23. Ben Haha, M., Weerdt, K., Lothenbach, B.: Quantification of the degree of reaction of fly ash. Cem. Concr. Res. 40, 1620-1629 (2010). 
24. Dyson, H.M., Richardson, I.G., Brough, A.R.: A Combined 29Si MAS NMR and Selective Dissolution Technique for the Quantitative Evaluation of Hydrated Blast Furnace Slag Cement Blends. J. Am. Ceram. Soc. 90, 598-602 (2007).

25. Luke, K., Glasser, F.P.: Selective dissolution of hydrated blast furnace slag cements. Cem. Concr. Res. 17, 273-282 (1987).

26. SFS-EN 451-1. (2004).

27. Yliniemi, J., Nugteren, H., Illikainen, M., Tiainen, M., Niinimäki, J.: Lightweight Aggregates Produced by Granulation of Peat-wood Fly Ash with Alkali Activator Manuscript submitted for review. (2014).

28. SFS EN 1097-6: Tests for mechanical and physical properties of aggregates. Part 6: Determination of particle density and water absorption. (2014).

29. EN 1097-3: Tests for mechanical and physical properties of aggregates. Part 3: Determination of loose bulk density and voids. (1998).

30. SFS-EN 12457-3: Characterisation of waste. Leaching. (2002).

31. Phyllis: Database for biomass and waste, (2000).

32. Keningley, S., Knight, P., Marson, A.: An investigation into the effects of binder viscosity on agglomeration behaviour. Powder Technol. 1997, 95-103 (1997).

33. Kristensen, H.: Particle agglomeration in high shear mixers. Powder Technol. 1996, 197-202 (1996).

34. SFS EN 13055-1: Lightweight Aggregates for Concrete, Mortar and Grout. (2002).

35. Wauters, P.A.L: Chapter 2 Mechanisms. In: Modelling and mechanisms of granulation. pp. 7$36(2001)$.

36. Li, Y., Wu, D., Zhang, J., Chang, L., Wu, D., Fang, Z., Shi, Y.: Measurement and statistics of single pellet mechanical strength of differently shaped catalysts. Powder Technol. 113, 176184 (2000).

37. ISO 11273-2: Soil quality determination of aggregate stability part 2: Method by shear test. (2000).

38. González-Corrochano, B., Alonso-Azcárate, J., Rodas, M., Barrenechea, J.F., Luque, F.J.: Microstructure and mineralogy of lightweight aggregates manufactured from mining and industrial wastes. Constr. Build. Mater. 25, 3591-3602 (2011).

39. González-Corrochano, B., Alonso-Azcárate, J., Rodas, M.: Production of lightweight aggregates from mining and industrial wastes. J. Environ. Manage. 90, 2801-2812 (2009).

40. González-Corrochano, B., Alonso-Azcárate, J., Rodas, M.: Characterization of lightweight aggregates manufactured from washing aggregate sludge and fly ash. Resour. Conserv. Recycl. 53, 571-581 (2009).

41. Álvarez-Ayuso, E., Querol, X., Plana, F., Alastuey, A., Moreno, N., Izquierdo, M., Font, O., Moreno, T., Diez, S., Vázquez, E., Barra, M.: Environmental, physical and structural characterisation of geopolymer matrixes synthesised from coal (co-)combustion fly ashes. J. Hazard. Mater. 154, 175-183 (2008).

42. Izquierdo, M., Querol, X., Phillipart, C., Antenucci, D., Towler, M.: The role of open and closed curing conditions on the leaching properties of fly ash-slag-based geopolymers. J. Hazard. Mater. 176, 623-628 (2010).

43. Škvára, F., Kopecký, L., Šmilauer, V., Bittnar, Z.: Material and structural characterization of alkali activated low-calcium brown coal fly ash. J. Hazard. Mater. 168, 711-720 (2009).

44. Ogundiran, M.B., Nugteren, H.W., Witkamp, G.J.: Immobilisation of lead smelting slag within spent aluminate - fly ash based geopolymers. J. Hazard. Mater. 248-249, 29-36 (2013).

45. Hupa, M.: Interaction of fuels in co-firing in FBC. Fuel. 84, 1312-1319 (2005).

46. Zevenhoven-Onderwater, M., Blomquist, J.-P., Skrifvars, B.-J., Backman, R., Hupa, M.: The prediction of behaviour of ashes from five different solid fuels in fluidised bed combustion. Fuel. 79, 1353-1361 (2000). 
47. Colangelo, F., Cioffi, R., Montagnaro, F., Santoro, L.: Soluble salt removal from MSWI fly ash and its stabilization for safer disposal and recovery as road basement material. Waste Manag. 32, 1179-1185 (2012).

48. FINLEX ® 591: http://www.finlex.fi/en/laki/kaannokset/2006/20060591.

49. Provis, J.L., Lukey, G.C., van Deventer, J.S.J.: Do Geopolymers Actually Contain Nanocrystalline Zeolites? A Reexamination of Existing Results. Chem. Mater. 17, 3075-3085 (2005).

50. García-Lodeiro, I., Fernández-Jiménez, A., Palomo, A., Macphee, D.E.: Effect of Calcium Additions on N-A-S-H Cementitious Gels. J. Am. Ceram. Soc. 93, 1934-1940 (2010).

12

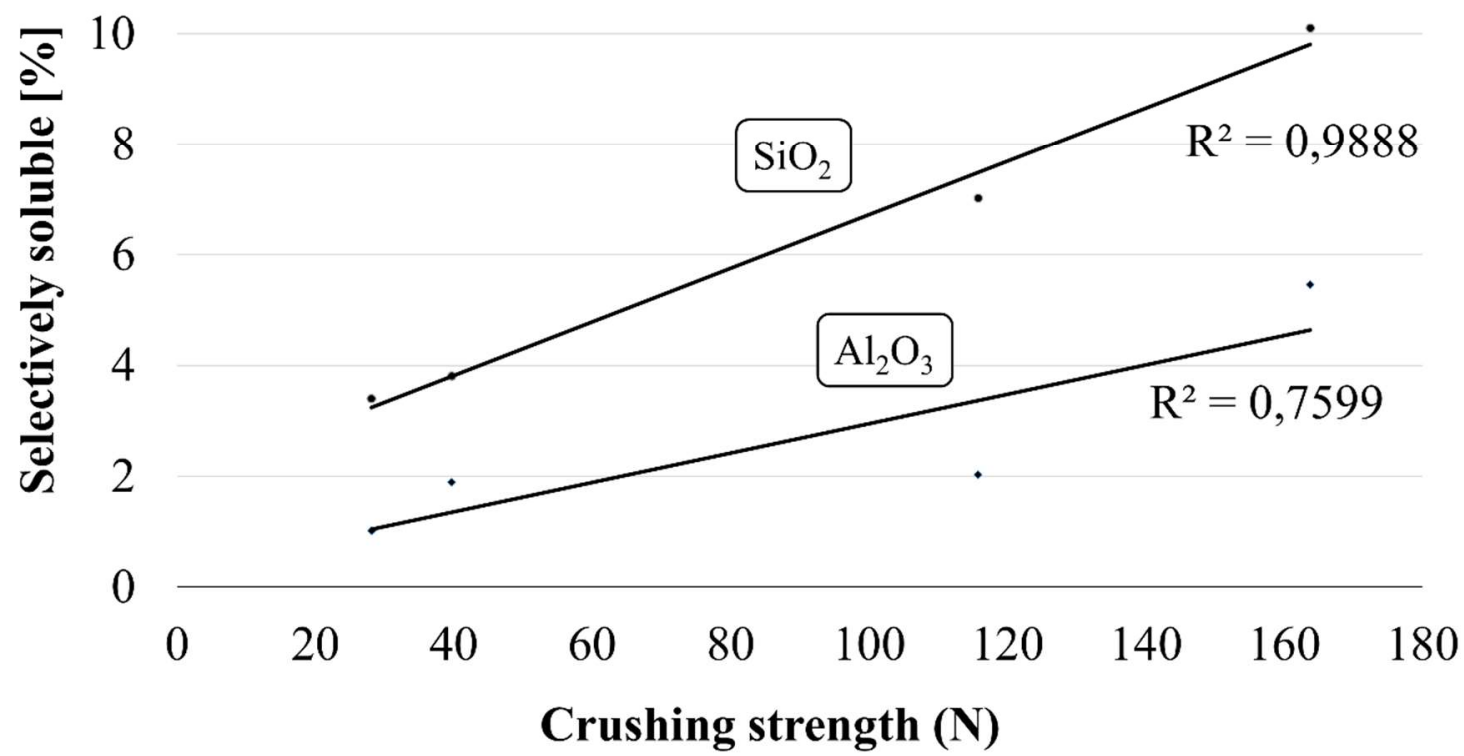

Fig. 1. Correlation between the crushing strength of the aggregates and selectively soluble $\mathrm{SiO}_{2}$ and $\mathrm{Al}_{2} \mathrm{O}_{3}$. 

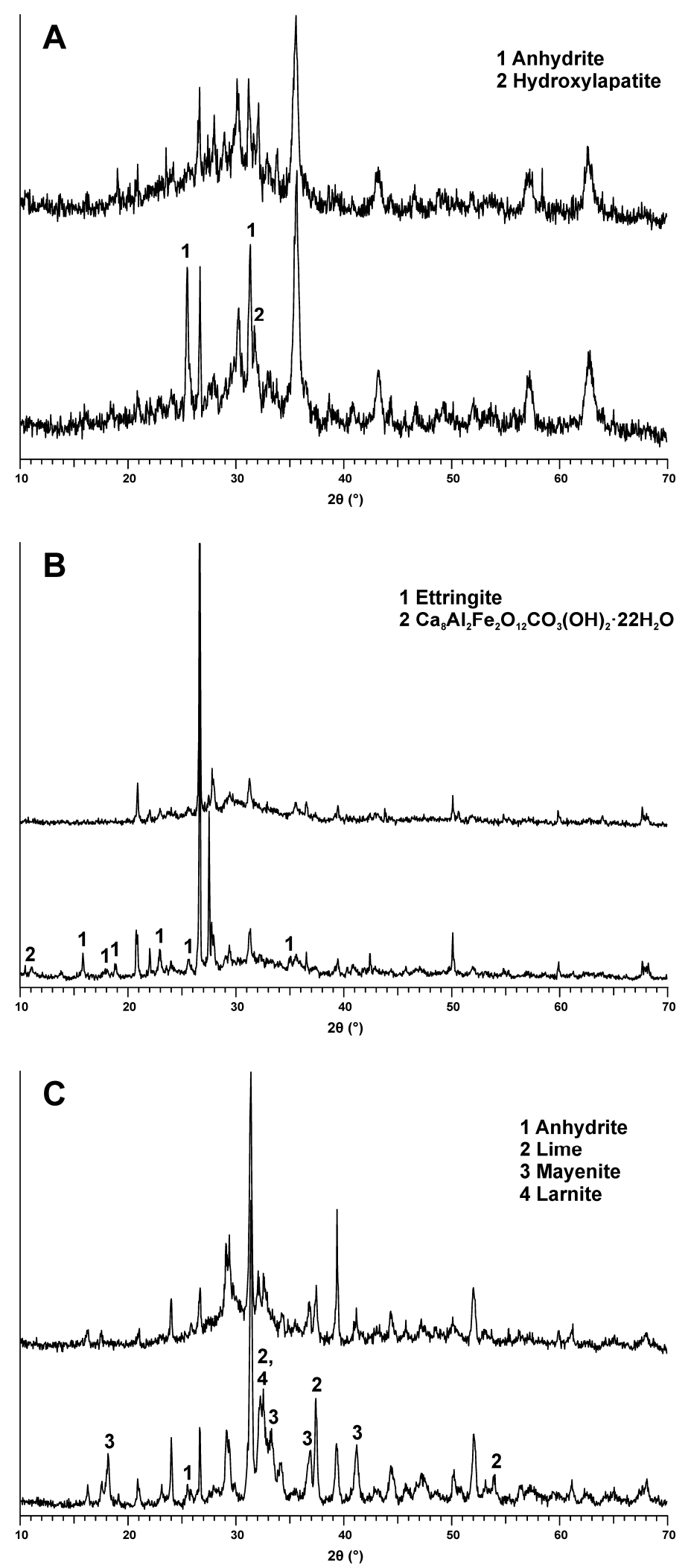


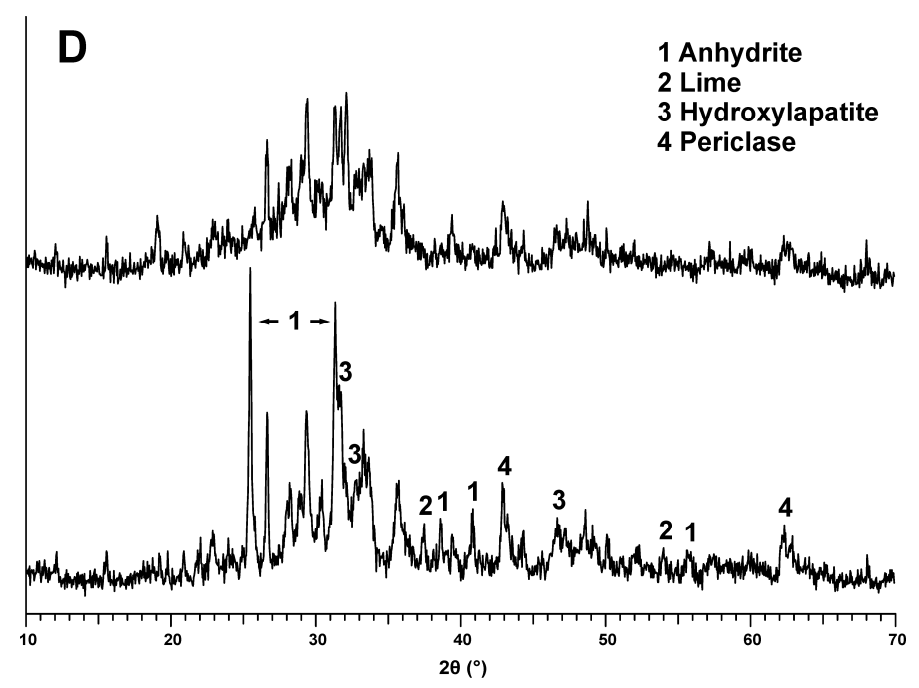

Fig. 2a-d. XRD diffractograms for fly ashes A, B, C, and D (lower graph in each) and their alkaliactivated counterparts (upper graphs). For clarity, only the phases that changed after alkali activation are marked. 